\title{
Bioenergetic constraints for conversion of syngas to biofuels in acetogenic bacteria
}

\author{
Johannes Bertsch and Volker Müller
}

\begin{abstract}
Synthesis gas (syngas) is a gas mixture consisting mainly of $\mathrm{H}_{2}, \mathrm{CO}$, and $\mathrm{CO}_{2}$ and can be derived from different sources, including renewable materials like lignocellulose. The fermentation of syngas to certain biofuels, using acetogenic bacteria, has attracted more and more interest over the last years. However, this technology is limited by two things: (1) the lack of complete knowledge of the energy metabolism of acetogenic bacteria, and (2) the lack of sophisticated genetic tools for the modification of acetogens. In this review, we discuss the bioenergetic constraints for the conversion of syngas to different biofuels. We will mainly focus on Acetobacterium woodii, which is the best understood acetogen in terms of energy conservation. Syngas fermentation with Clostridium autoethanogenum will also be discussed, since this organism is well suited to convert syngas to certain products and already used in large-scale industrial processes.
\end{abstract}

Keywords: Synthesis gas fermentation, Acetogenic bacteria, Biofuels, Acetobacterium woodii, Clostridium autoethanogenum

\section{Background}

The finiteness of fossil energy sources and the negative effects of global warming as a consequence of the $\mathrm{CO}_{2}$ emissions have led to an increasing demand to develop new technologies for the usage of renewable energy sources. For the production of electricity, eco-friendly technologies like the usage of wind, heat, and solar power are highly developed and make an appreciable contribution to the demand of electricity. However, the fuel industry as well as the production of commodities required for industrial processes is almost completely based on crude oil. Many technologies using different strategies are developed to produce the corresponding biofuels from alternative energy sources, but so far no technology has evolved which would lead to independence of the industry on crude oil.

Whether the production of biofuels from renewable energy sources is eco-friendly and sustainable depends mainly on the feedstock used. The usage of crops (sugar cane, wheat, corn) for the generation of first-generation

\footnotetext{
*Correspondence: vmueller@bio.uni-frankfurt.de

Department of Molecular Microbiology and Bioenergetics, Institute

of Molecular Biosciences, Johann Wolfgang Goethe University,

Max-von-Laue-Str. 9, 60438 Frankfurt, Germany
}

biofuels is in conflict with production of food for mankind $[1,2]$. Therefore, a lot of efforts are being made to use non-food crops or residues as feedstock. The biomass used contains high amounts of lignocellulose, which has to be digested chemically and enzymatically before it can be fermented. Appropriate organisms have to be genetically modified in order to be able to use the hemicellulose-derived $\mathrm{C}_{5}$ sugars (pentoses) which can make up to $30 \%$ in lignocellulose [3]. Another possibility is the gasification of the biomass, which leads to a gas mixture called synthesis gas (syngas). Syngas mainly consists of $\mathrm{H}_{2}, \mathrm{CO}$, and $\mathrm{CO}_{2}$ and can be used in the Fischer-Tropsch process to chemically produce synthetic fuels [4]. For biotechnological applications, it is important to note that syngas derived from different sources differs with respect to the ratio of $\mathrm{H}_{2}, \mathrm{CO}$, and $\mathrm{CO}_{2}$ [5]. In addition, syngas often contains side products such as sulfur, chlorine, or ammonia that are inhibitory to bacterial growth [6].

Syngas can also be metabolized by bacteria such as Eubacterium limosum [7], Clostridium autoethanogenum [8], or Acetobacterium woodii [9]. They belong to the group of strictly anaerobic, acetogenic bacteria, many of which grow on $\mathrm{H}_{2}+\mathrm{CO}_{2}$ or $\mathrm{CO}$ or mixtures of both. These bacteria can use syngas as carbon and energy 
source. Naturally occurring end-products are acetate, but also ethanol, butanol, butyrate, lactate, and 2,3-butanediol $(2,3-\mathrm{BD})[10,11]$. In the last years, tremendous progress was made in developing acetogens by metabolic engineering to convert syngas to biofuels [12]. However, the energetics of product formation from $\mathrm{H}_{2}+\mathrm{CO}_{2}$ and $\mathrm{CO}$ are only poorly understood in most acetogens. This, though, is a prerequisite for predicting the carbon and electron flow in a certain production pathway, which is required for optimizing the technology up to a production level where it becomes industrially attractive. The focus of this review is to describe bioenergetic constraints for the production of biofuels from syngas using acetogenic bacteria.

\section{Review}

\section{Energy conservation in acetogens}

Acetogens convert $\mathrm{H}_{2}+\mathrm{CO}_{2}$ to acetate according to Eq. 1:

$$
\begin{aligned}
& 4 \mathrm{H}_{2}+2 \mathrm{CO}_{2} \rightarrow 1 \mathrm{CH}_{3} \mathrm{COO}^{-}+1 \mathrm{H}^{+}+2 \mathrm{H}_{2} \mathrm{O} \\
& \Delta G^{0 \prime}=-95 \mathrm{~kJ} / \mathrm{mol}
\end{aligned}
$$

Acetate formation from CO proceeds via Eq. 2:

$$
\begin{aligned}
4 \mathrm{CO}+2 \mathrm{H}_{2} \mathrm{O} & \rightarrow 1 \mathrm{CH}_{3} \mathrm{COO}^{-}+1 \mathrm{H}^{+}+2 \mathrm{CO}_{2} \\
\Delta G^{0 \prime} & =-175 \mathrm{~kJ} / \mathrm{mol}
\end{aligned}
$$

$\mathrm{CO}_{2}$ and $\mathrm{CO}$ are converted to acetate via the WoodLjungdahl pathway (WLP). The enzymology of the WLP has been reviewed in great detail [13-15] and will be summarized here only briefly to an extent necessary to be able to follow the argumentation. In the methyl branch, $\mathrm{CO}_{2}$ is reduced to formate which is condensed in an ATPdependent reaction with tetrahydrofolate (THF) to yield formyl-THF (Fig. 1). Water is split off, and the resulting methenyl-THF is reduced via methylene- to methyl-THF. The methyl group is transferred via a methyl transferase and a corrinoid-iron-sulfur protein to the $\mathrm{CO}$ dehydrogenase/acetyl-CoA synthase (CODH/ACS). In the carbonyl branch, $\mathrm{CO}_{2}$ is reduced by $\mathrm{CODH} / \mathrm{ACS}$ to $\mathrm{CO}$. In the next step, the methyl group, the carbonyl group, and coenzyme A are condensed to acetyl-CoA which is further converted by phosphotransacetylase and acetate kinase to acetate. The latter reaction yields one ATP. In sum, the ATP yield by substrate-level phosphorylation is zero.

Electrons for the reduction pathway are generated by oxidation of molecular hydrogen, catalyzed by electronbifurcating hydrogenases [16]. This novel mechanism of energy coupling [17] enables the reduction of ferredoxin $\left(E_{0}{ }^{\prime} \approx-500 \mathrm{mV}\right)$ with hydrogen $\left(E_{0}{ }^{\prime}=-414 \mathrm{mV}\right)$, an endergonic reaction that is driven by simultaneous,

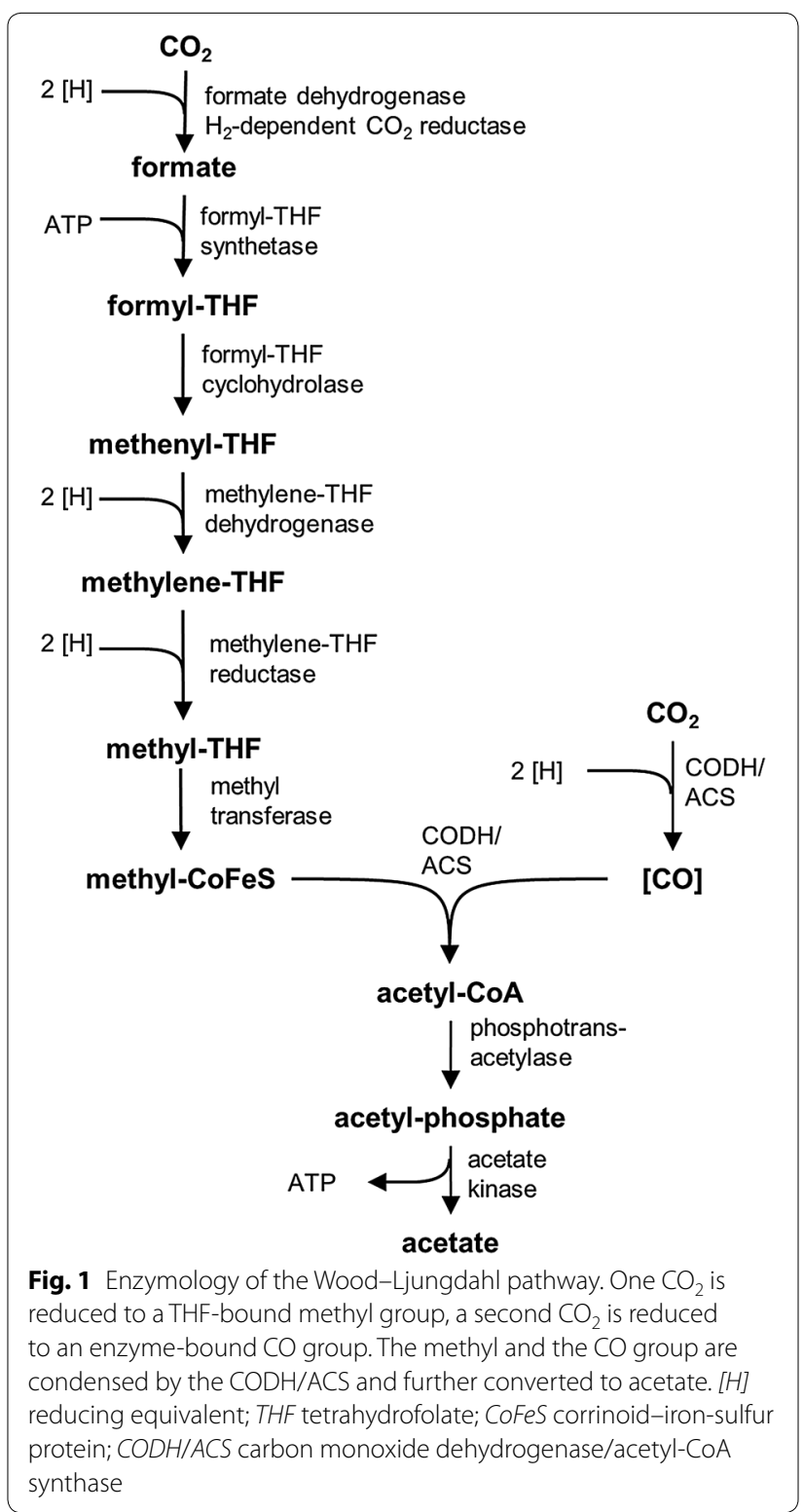

exergonic electron transfer from $\mathrm{H}_{2}$ to $\mathrm{NAD}(\mathrm{P})^{+}$ $\left(E_{0}{ }^{\prime}=-320 \mathrm{mV}\right)$.

If $\mathrm{CO}$ is the electron donor, $\mathrm{CO}$ dehydrogenases (CODHs) catalyze the oxidation of $\mathrm{CO}$ to $\mathrm{CO}_{2}$ [18]. Due to the low redox potential of the $\mathrm{CO} / \mathrm{CO}_{2} \mathrm{cou}$ ple $\left(E_{0}{ }^{\prime}=-520 \mathrm{mV}\right)$, a low potential ferredoxin $\left(E_{0}{ }^{\prime} \approx-500 \mathrm{mV}\right)$ can be reduced directly. Reduced ferredoxin $\left(\mathrm{Fd}^{2-}\right)$ is the key electron donor in cellular bioenergetics in acetogens [19]. It is oxidized by membrane-bound, electron transfer enzymes that couple exergonic electron transfer to an acceptor with the translocation of ions across the membrane, thus establishing an electrochemical ion gradient across the membrane 
[19]. To date, only two classes of energy-conserving chemiosmotic enzymes are known in acetogens: the ferredoxin: $\mathrm{NAD}^{+}$oxidoreductase (Rnf) $[20,21]$ and the ferredoxin: $\mathrm{H}^{+}$oxidoreductase (Ech) [22]. The ion translocated can be either a sodium ion or a proton. The electron transfer from $\mathrm{Fd}^{2-}$ to $\mathrm{NAD}^{+}$via $\operatorname{Rnf}\left(\Delta G^{0 \prime}=-25 \mathrm{~kJ} /\right.$ mol) would allow the transfer of $2 \mathrm{Na}^{+} / \mathrm{H}^{+}$across the membrane, assuming a transmembrane electrochemical ion potential of $-180 \mathrm{mV}$ [19]. The electron transfer from $\mathrm{Fd}^{2-}$ to $\mathrm{H}^{+}$via Ech $\left(\Delta G^{0 \prime}=-7 \mathrm{~kJ} / \mathrm{mol}\right)$ releases less energy and is strongly dependent on the hydrogen pressure.

Although the basic chemistry used by acetogens to produce acetate from $\mathrm{H}_{2}+\mathrm{CO}_{2}$ or $\mathrm{CO}$ is identical, acetogens have an astonishing repertoire of different enzymes to catalyze these reactions. For bioenergetics considerations, it is noteworthy, (1) that they differ in the reductant used for reduction of $\mathrm{CO}_{2}$ to formate, (2) whether or not the methylene-THF reductase (MTHFR) uses electron bifurcation to reduce ferredoxin, (3) the presence or absence of transhydrogenases, and (4) the chemiosmotic enzyme catalyzing energy conservation.

In this review, we will mainly focus on $A$. woodii, which is the best understood acetogen in terms of energy conservation and is known for its industrial potential for producing acetic acid from $\mathrm{H}_{2}+\mathrm{CO}_{2}$ [23, 24]. In addition, we will discuss syngas fermentation with $C$. autoethanogenum, which is used in large-scale industrial processes due to its ability to convert syngas to acetate and ethanol and also traces of lactate and 2,3-BD $[8,25]$.

\section{Basic principles for calculating energy balances}

The amount of ATP which can be synthesized per mol acetate produced in the WLP is mainly dependent on the enzymes catalyzing the four redox steps and their demand of reduced ferredoxin. The higher the imbalance between demand and supply of reduced ferredoxin, the more $\mathrm{Na}^{+} / \mathrm{H}^{+}$can be translocated by the Rnf or Ech complex. If the amount of ions required for ATP synthesis via the ATP synthase is known, exact calculations can be done concerning ATP yields. In A. woodii, the reductant used by every enzyme of the pathway is known (Fig. 2) [19]. Reduction of $\mathrm{CO}_{2}$ to formate is catalyzed by a $\mathrm{H}_{2}$-dependent $\mathrm{CO}_{2}$ reductase (HDCR) [26], and reduction of $\mathrm{CO}_{2}$ to $\mathrm{CO}$ is catalyzed by the CODH/ACS with $\mathrm{Fd}^{2-}$ as electron donor [27]. The reactions catalyzed by the methylene-THF dehydrogenase [28] and the MTHFR [29] require NADH for reduction. Thus, reduction of 2 $\mathrm{CO}_{2}$ to acetate requires $1 \mathrm{H}_{2}, 2 \mathrm{NADH}$, and $1 \mathrm{Fd}^{2-}$.

With hydrogen as electron donor, oxidation of $3 \mathrm{H}_{2}$ via the electron-bifurcating hydrogenase [16] gives 1.5 $\mathrm{NADH}$ and $1.5 \mathrm{Fd}^{2-} .0 .5 \mathrm{Fd}^{2-}$ are oxidized at the $\mathrm{Rnf}$ complex, which is coupled to the translocation of $1 \mathrm{Na}^{+}$ out of the cell. The ATP synthase of $A$. woodii requires 3.3 $\mathrm{Na}^{+}$for the synthesis of 1 ATP [30], thus the $1 \mathrm{Na}^{+}$translocated by the Rnf complex leads to synthesis of 0.3 ATP. Therefore, the synthesis of acetate from $\mathrm{H}_{2}+\mathrm{CO}_{2}$ leads to formation of 0.3 ATP:

$$
\begin{aligned}
& 4 \mathrm{H}_{2}+2 \mathrm{CO}_{2}+0.3 \mathrm{ADP}+0.3 \mathrm{P}_{\mathrm{i}} \\
& \rightarrow 1 \text { acetate }+0.3 \mathrm{ATP} .
\end{aligned}
$$

Since the $\mathrm{H}$-clusters of most hydrogenases are inhibited by $\mathrm{CO}$, the reduction of $\mathrm{CO}_{2}$ to formate which is catalyzed by the HDCR in $A$. woodii is a bottleneck for formation of acetate if $\mathrm{CO}$ is the electron donor [9]. Using $\mathrm{CO}$ as electron donor, acetate formation from $\mathrm{CO} / \mathrm{CO}_{2}$ via the WLP would require $1 \mathrm{H}_{2}$ and $2 \mathrm{NADH}$ (Fig. 3). The oxidation of $3 \mathrm{CO}$ by the CODH/ACS yields $3 \mathrm{Fd}^{2-}$, whereof $2.5 \mathrm{Fd}^{2-}$ have to be oxidized at the Rnf complex. $0.5 \mathrm{Fd}^{2-}$ and $0.5 \mathrm{NADH}$ are converted to $1 \mathrm{H}_{2}$ by the electron-bifurcating hydrogenase. The Rnf complex translocates $5 \mathrm{Na}^{+}$which leads to the synthesis of 1.5 ATP via the ATP synthase. Thus, acetate formation from $\mathrm{CO}$ has a 5 times higher ATP yield as from $\mathrm{H}_{2}+\mathrm{CO}_{2}$ :

$$
\begin{aligned}
& 4 \mathrm{CO}+1.5 \mathrm{ADP}+1.5 \mathrm{P}_{\mathrm{i}} \rightarrow 1 \text { acetate } \\
& +2 \mathrm{CO}_{2}+1.5 \mathrm{ATP}
\end{aligned}
$$

Many pathways leading to a desired product start with acetyl-CoA as precursor, and thus, if acetate is not produced, one ATP is missing in the balance. Therefore, acetyl-CoA formation from $\mathrm{H}_{2}+\mathrm{CO}_{2}$ has an ATP demand of 0.7 ATP, while from $\mathrm{CO}$, the formation of acetyl-CoA still yields 0.5 ATP.

It is important to know whether the further pathway leading to the desired product requires or produces ATP, then it can be calculated if the production from $\mathrm{H}_{2}+\mathrm{CO}_{2}$ or from $\mathrm{CO}$ has a positive energy balance. A negative energy balance will be compensated by producing side products (like acetate) which lead to the production of ATP.

ATP can be generated/consumed via substrate-level phosphorylation or via chemiosmosis, in $A$. woodii via the Rnf complex and the ATP synthase. The Rnf complex can translocate $2 \mathrm{Na}^{+}$per $\mathrm{Fd}^{2-}$ oxidized, which leads to formation of 0.6 ATP by the ATP synthase. Both reactions are reversible, thus the hydrolysis of 0.6 ATP at the ATP synthase leads to translocation of $2 \mathrm{Na}^{+}$which drives the endergonic electron transfer from NADH to $\mathrm{Fd}$. Therefore, the electron transfer from $\mathrm{Fd}^{2-}$ to $\mathrm{NAD}^{+}$ leads to production of $0.6 \mathrm{ATP}$ per $\mathrm{Fd}^{2-}$ oxidized, while the electron transfer from NADH to Fd requires an input of 0.6 ATP per NADH oxidized. For further calculations, it is important to calculate the amount of ATP which is generated or has to be invested for supplying an internal electron donor (NADH or $\mathrm{Fd}^{2-}$ ) by oxidation of an external electron donor $\left(\mathrm{CO}\right.$ or $\left.\mathrm{H}_{2}\right)$. If $\mathrm{CO}$ is the external 


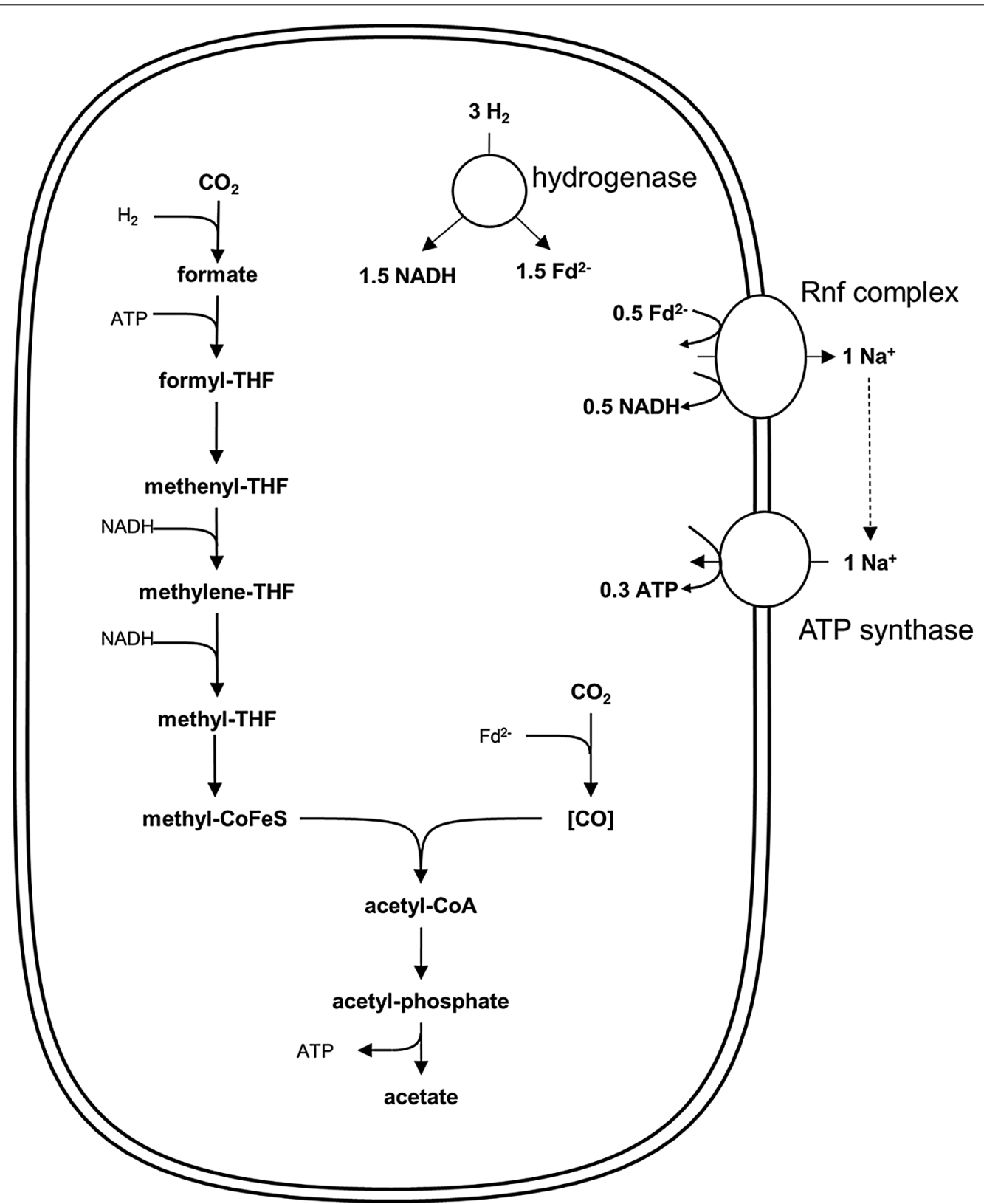

Fig. 2 Bioenergetics of acetate formation from $\mathrm{H}_{2}+\mathrm{CO}_{2}$ in A. woodii. The reducing equivalents for the reductive steps in the WLP are provided by an $\mathrm{H}_{2}$-oxidizing, electron-bifurcating hydrogenase which reduces $\mathrm{Fd}$ and $\mathrm{NAD}^{+}$. Excess $\mathrm{Fd}^{2-}$ is oxidized by the Rnf complex which reduces $\mathrm{NAD}^{+}$ and builds up a $\mathrm{Na}^{+}$gradient. This gradient drives ATP synthesis via the $\mathrm{Na}^{+}$-dependent ATP synthase. In total, 0.3 ATP could be synthesized per acetate produced. THF tetrahydrofolate; CoFeS corrinoid-iron-sulfur protein

electron donor, the oxidation by the CODH yields only $\mathrm{Fd}^{2-}$. Therefore, having $\mathrm{CO}$ as electron donor the supply of $\mathrm{Fd}^{2-}$ neither requires investment of ATP nor produces ATP. If NADH is required, the CO-derived $\mathrm{Fd}^{2-}$ is converted into NADH via the Rnf complex, which leads to formation of 0.6 ATP by the ATP synthase. If $\mathrm{H}_{2}$ is the external electron donor, the oxidation by the bifurcating hydrogenase yields $0.5 \mathrm{NADH}$ and $0.5 \mathrm{Fd}^{2-}$. Therefore, for supplying only $\mathrm{Fd}^{2-}$ from $\mathrm{H}_{2}, 0.3$ ATP have to be invested for converting $0.5 \mathrm{NADH}$ into $0.5 \mathrm{Fd}^{2-}$ via a reversal of the Rnf-catalyzed reaction. For supplying only $\mathrm{NADH}$ from $\mathrm{H}_{2}, 0.3$ ATP are produced upon conversion of $0.5 \mathrm{Fd}^{2-}$ into $0.5 \mathrm{NADH}$.

Next, we will discuss different production pathways leading to the formation of products like ethanol, butanol, or isoprene, starting with acetyl-CoA as precursor (Table 1). As deduced above, the reduction of $\mathrm{CO}_{2}$ to acetyl-CoA with $\mathrm{H}_{2}$ requires 0.7 ATP, whereas with $\mathrm{CO}$ 


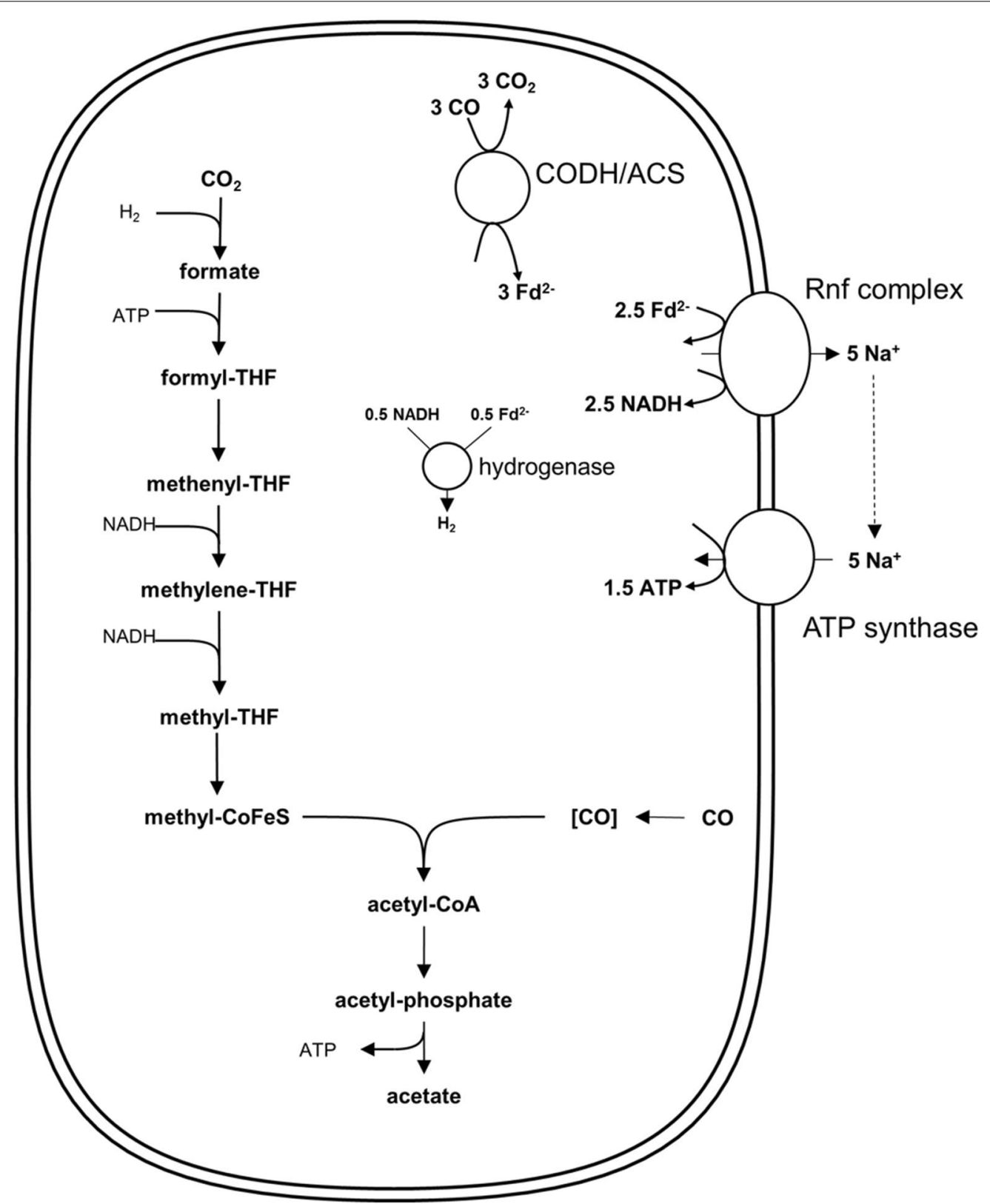

Fig. 3 Bioenergetics of acetate formation from CO in A. woodii. The reducing equivalents for the reductive steps in the WLP are provided by the $\mathrm{CO}$-oxidizing $\mathrm{CODH} / \mathrm{ACS}$ which reduces Fd. Excess $\mathrm{Fd}^{2-}$ is oxidized by the $\mathrm{Rnf}$ complex which reduces $\mathrm{NAD}^{+}$and builds up a Na ${ }^{+}$gradient. This gradient drives ATP synthesis via the $\mathrm{Na}^{+}$-dependent ATP synthase. The electron-bifurcating hydrogenase provides the $\mathrm{H}_{2}$ required for the reduction of $\mathrm{CO}_{2}$ to formate. In total, 1.5 ATP could be synthesized per acetate produced. THF tetrahydrofolate; CoFeS corrinoid-iron-sulfur protein; $\mathrm{CODH} / \mathrm{ACS}$ carbon monoxide dehydrogenase/acetyl-CoA synthase

as donor, 0.5 ATP is produced. Therefore, if the further conversion of acetyl-CoA to the desired product has a positive energy balance, the overall production from $\mathrm{CO}$ will be positive, from $\mathrm{H}_{2}+\mathrm{CO}_{2}$ it depends on the amount of ATP produced. If the pathway to the desired product from acetyl-CoA requires an input of ATP, the energy balance for production from $\mathrm{H}_{2}+\mathrm{CO}_{2}$ will be negative, from $\mathrm{CO}$ it depends on the amount of energy required. 
Table 1 ATP yield for the synthesis of products from acetyl-CoA with $\mathrm{H}_{2}$ or $\mathrm{CO}$ as electron donor

\begin{tabular}{|c|c|c|c|c|}
\hline \multirow[t]{2}{*}{ Product } & \multirow[t]{2}{*}{ Key enzymes/intermediates } & \multirow[t]{2}{*}{ Conversion (acetyl-CoA as precursor) } & \multicolumn{2}{|c|}{ ATP yield } \\
\hline & & & $\mathrm{H}_{2}$ & $\mathrm{CO}$ \\
\hline Acetate & Acetate kinase & Acetyl-CoA $\rightarrow$ acetate & 0.3 & 1.5 \\
\hline \multirow[t]{2}{*}{ Ethanol } & Acetaldehyde DH & Acetyl-CoA $\rightarrow$ ethanol & -0.1 & 1.7 \\
\hline & $\mathrm{AOR}$ & & 0.3 & 2.1 \\
\hline \multirow[t]{4}{*}{ Butanol } & $\mathrm{BDH}$ & 2 acetyl-CoA $\rightarrow$ butanol & -0.2 & 3.4 \\
\hline & $\mathrm{BDH}$, bifurcating Bcd & & 0.4 & 4.0 \\
\hline & $\mathrm{AOR}$ & & 0.2 & 3.8 \\
\hline & AOR, bifurcating Bcd & & 0.8 & 4.4 \\
\hline Isoprene & Mevalonate & 3 acetyl-CoA $\rightarrow$ isoprene $+\mathrm{CO}_{2}$ & -4.5 & -0.3 \\
\hline \multirow[t]{2}{*}{ Lactate } & NADH-dependent LDH & Acetyl-CoA $+\mathrm{CO}_{2} \rightarrow$ lactate & -0.7 & 1.1 \\
\hline & Bifurcating LDH & & -0.1 & 1.7 \\
\hline 2,3-Butanediol & Acetolactate synthase & 2 acetyl-CoA $\rightarrow 2,3$-butanediol & -1.7 & 1.6 \\
\hline Acetone & Acetoacetate & 2 acetyl-CoA $\rightarrow$ acetone $+\mathrm{CO}_{2}$ & -0.4 & 2.0 \\
\hline Isobutene & Acetone, 3-OH-isovalerate & 3 acetyl-CoA $\rightarrow$ isobutene $+2 \mathrm{CO}_{2}$ & -2.1 & 1.5 \\
\hline
\end{tabular}

\section{Production of biofuels}

Production of ethanol

Ethanol is globally used as feedstock for the chemical industry, as energy carrier and in alcoholic beverages. It can be used as fuel additive, with certain modifications, engines can be altered to run on $100 \%$ ethanol. Ethanol can be made from acetyl-CoA by two reduction steps via acetaldehyde (Fig. 4). The reduction of acetyl-CoA to ethanol with $\mathrm{NADH}$ as electron donor is close to equilib$\operatorname{rium}\left(\Delta G^{0 \prime}=-6.2 \mathrm{~kJ} / \mathrm{mol}[31]\right)$ and catalyzed by NADHdependent enzymes like the bifunctional AdhE [32-34]. Thus, 2 NADH are required for the reduction of acetylCoA to ethanol. As delineated before, the reduction of 2 $\mathrm{NAD}^{+}$with $\mathrm{H}_{2}$ as electron donor yields 0.6 ATP by action of hydrogenase, Rnf complex, and ATP synthase. Thus, the production of ethanol from acetyl-CoA (with $\mathrm{H}_{2}$ as reductant) yields 0.6 ATP. However, the production of acetyl-CoA from $\mathrm{H}_{2}+\mathrm{CO}_{2}$ requires 0.7 ATP, and therefore, the production of ethanol from $\mathrm{H}_{2}+\mathrm{CO}_{2}$ via acetaldehyde dehydrogenase $(\mathrm{AldDH})$ requires an input of 0.1 ATP/ethanol (Eq. 5).

$$
6 \mathrm{H}_{2}+2 \mathrm{CO}_{2}+0.1 \mathrm{ATP} \rightarrow 1 \text { ethanol }
$$

Ethanol formation from $\mathrm{H}_{2}+\mathrm{CO}_{2}$ via this pathway is not possible if the synthesis of acetyl-CoA costs more than 0.6 ATP, and therefore, this pathway cannot be implemented by metabolic engineering. However, there is a second way of producing ethanol from acetyl-CoA. Aldehyde:ferredoxin oxidoreductases (AOR; EC 1.2.7.5) are capable of catalyzing the reversible reduction of an acid to the corresponding aldehyde [35], in this case, the reduction of acetate to acetaldehyde. The redox potential of acetate/acetaldehyde $\left(E_{0}{ }^{\prime}=-580 \mathrm{mV}\right)$ is so negative

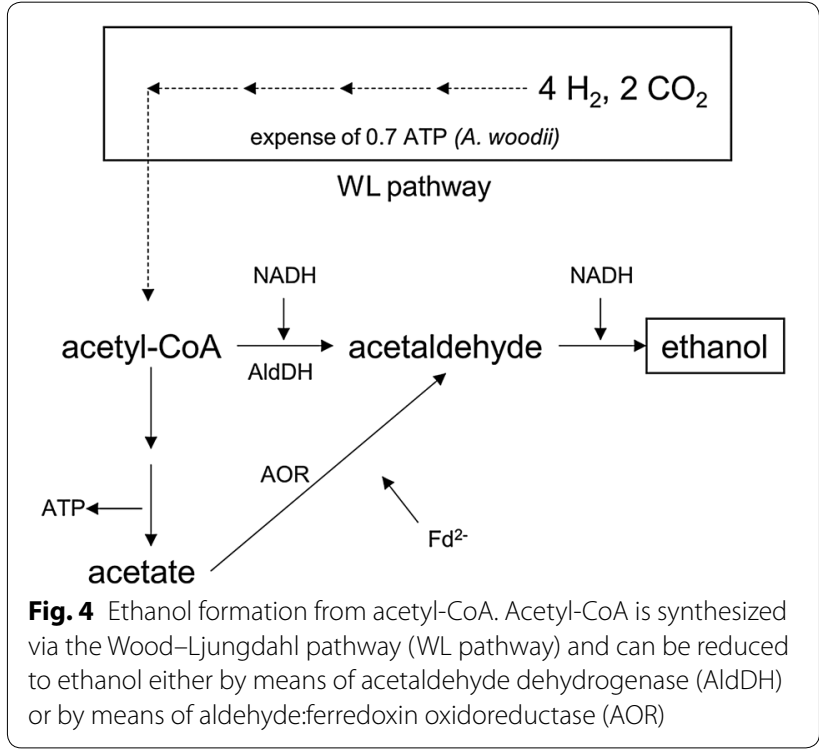

that a low potential electron donor such as ferredoxin is required. The further reduction of acetaldehyde to ethanol could be catalyzed by a monofunctional alcohol dehydrogenase $(\mathrm{ADH})$, or by the same AdhE as described above [36]. Since acetate is formed, the acetate kinase produces 1 ATP via substrate-level phosphorylation. The two consequent reduction steps require $1 \mathrm{Fd}^{2-}$ and $1 \mathrm{NADH}$, which is provided by the electron-bifurcating hydrogenase. Thus, the reduction of acetyl-CoA to ethanol (with $\mathrm{H}_{2}$ ) via acetate by the AOR pathway yields 1 ATP, while production of acetyl-CoA from $\mathrm{H}_{2}+\mathrm{CO}_{2}$ requires only $0.7 \mathrm{ATP}$.

$$
6 \mathrm{H}_{2}+2 \mathrm{CO}_{2} \rightarrow 1 \text { ethanol }+0.3 \mathrm{ATP}
$$


Table 2 Potential aldehyde: ferredoxin oxidoreductases (AORs) in acetogens

\begin{tabular}{|c|c|c|c|}
\hline \multirow[t]{2}{*}{ Organism } & \multirow[t]{2}{*}{ Gene $^{a}$} & \multicolumn{2}{|l|}{ Annotation } \\
\hline & & Aldehyde:Fd oxidoreductase & Formaldehyde:Fd oxidoreductase \\
\hline \multirow[t]{2}{*}{ Clostridium ljungdahlii } & CLJU_C20210 & + & \\
\hline & CLJU_c20110 & + & \\
\hline \multirow[t]{2}{*}{ Clostridium autoethanogenum } & CAETHG_0092 & + & \\
\hline & CAETHG_0102 & + & \\
\hline Clostridium acetobutylicum & SMB_G2050 & + & \\
\hline \multirow[t]{3}{*}{ Eubacterium limosum KIST612 } & ELI_0332 & + & \\
\hline & ELI_1752 & + & \\
\hline & ELI_3389 & + & \\
\hline Acetobacterium woodii & Awo_c12420 & & + \\
\hline \multirow[t]{2}{*}{ Moorella thermoacetica } & Moth_0154 & + & \\
\hline & Moth_0722 & + & \\
\hline \multirow[t]{3}{*}{ Pyrococcus furiosus ${ }^{\mathrm{b}}$} & PF1203 & + & \\
\hline & PF0346 & & + \\
\hline & PF1961 & & + \\
\hline \multirow[t]{6}{*}{ Thermacetogenium phaeum } & Tph_c04180 & + & \\
\hline & Tph_c07080 & + & \\
\hline & Tph_c08220 & + & \\
\hline & Tph_c19480 & + & \\
\hline & Tph_c20350 & + & \\
\hline & Tph_c27630 & + & \\
\hline
\end{tabular}

a Gene accession numbers are from the KEGG database

b Pyrococcus furiosus is not an acetogen but a hyperthermophilic archaeon in which the AOR pathway has been demonstrated [36]

In total, ethanol production from $\mathrm{H}_{2}+\mathrm{CO}_{2}$ via the AOR pathway has a positive energy balance and, therefore, should be feasible. Indeed, aldehyde:ferredoxin oxidoreductases can be found in the genomes of many acetogens (Table 2). These enzymes have in common that they have tungsten (W) as cofactor. So far, the structures of the AOR [37] and the formaldehyde:ferredoxin oxidoreductase (FOR) [38] of Pyrococcus furiosus have been published. Both proteins contain an $\mathrm{Fe}_{4} \mathrm{~S}_{4}$ cluster which is coordinated by four cysteine residues. The molybdopterin-based tungsten cofactor is coordinated by a total of 16 (AOR) and 12 (FOR) amino acid residues which are distributed over the amino acid sequence. The genome of $A$. woodii harbors only one gene which encodes for a putative FOR (KEGG: Awo_c12420). It is annotated as "tungsten-containing formaldehyde ferredoxin oxidoreductase"; however, it is only 29 and $31 \%$ identical to the AOR and the FOR of $P$. furiosus, respectively. It is not surprising that only 2 of the 4 cysteine residues required for coordinating the $\mathrm{Fe}_{4} \mathrm{~S}_{4}$ cluster are present, and of the residues required for binding the tungsten, only $6 / 16$ (AOR) and 4/12 (FOR) are present. Thus, $A$. woodii most probably lacks a functional AOR, which would be the reason that this species has never found to produce ethanol from $\mathrm{H}_{2}+\mathrm{CO}_{2}$.
If $\mathrm{CO}$ is used as electron donor, the production of acetyl-CoA is coupled to the production of $0.5 \mathrm{ATP} /$ acetyl-CoA. Since the further conversion of acetyl-CoA to ethanol yields also ATP (1.2-1.6 ATP), production of ethanol from $\mathrm{CO}$ will be energy positive, independent which of the two pathways is used. However, ethanol production from $\mathrm{CO}$ will be coupled to $\mathrm{CO}_{2}$ production, according to Eq. 7:

$$
6 \mathrm{CO} \rightarrow 1 \text { ethanol }+4 \mathrm{CO}_{2} .
$$

Therefore, the ATP yield for ethanol production from $\mathrm{CO}$ is higher than for acetate production from $\mathrm{CO}$. And indeed, some acetogens like C. autoethanogenum (see "Production of biofuels using Clostridium autoethanogenum") produce ethanol when growing on $\mathrm{CO}$ [8].

\section{Production of butanol}

Butanol is required in large scale in the chemical industry as solvent. As fuel additive, it has even better properties than ethanol, since it is not hygroscopic and therefore does not lead to corrosion of the engines [39].

Butanol is produced from $\mathrm{H}_{2}+\mathrm{CO}_{2}$ according to

$$
12 \mathrm{H}_{2}+4 \mathrm{CO}_{2} \rightarrow 1 \text { butanol. }
$$




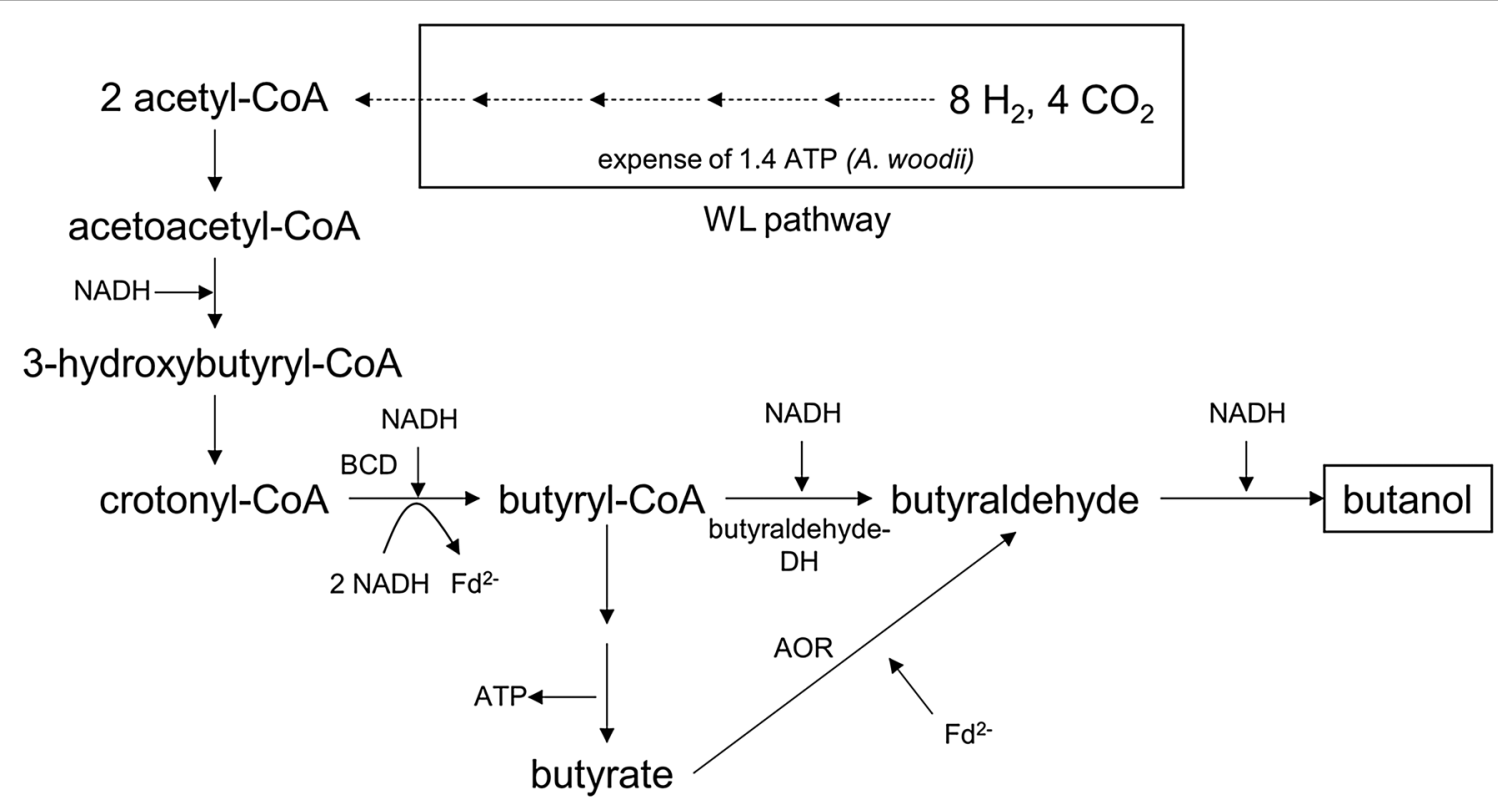

Fig. 5 Butanol formation from acetyl-CoA. Acetyl-CoA is synthesized via the Wood-Ljungdahl pathway (WL pathway) and 2 acetyl-CoA can be reduced to butanol either by means of butyraldehyde dehydrogenase or by means of aldehyde:ferredoxin oxidoreductase (AOR). The butyryl-CoA dehydrogenase $(\mathrm{Bcd})$ uses NADH as electron donor, if the Bcd is electron-bifurcating it reduces ferredoxin simultaneously with crotonyl-CoA

For the production of the $\mathrm{C}_{4}$ molecule butanol, 2 molecules of acetyl-CoA are required, and therefore, 1.4 ATP have to be invested with $\mathrm{H}_{2}$ as electron donor (Fig. 5). Two molecules of acetyl-CoA are condensed to acetoacetyl-CoA which is reduced to 3-hydroxypropionylCoA with NADH. After water is split of, crotonyl-CoA is reduced to butyrate by a butyryl-CoA dehydrogenase (Bcd). Due to the positive redox potential of the crotonyl-CoA/butyryl-CoA couple $\left(E_{0}{ }^{\prime}=-10 \mathrm{mV}\right)$, NADHdependent Bcds catalyze this exergonic reaction. The Bcd of Clostridium kluyveri is the prototype of a flavindependent, electron-bifurcating enzyme [40]. It uses the exergonic reaction of the NADH-dependent reduction of crotonyl-CoA to drive reduction of ferredoxin with NADH. Recently, we have demonstrated the presence of an electron-bifurcating Bcd in E. limosum KIST612, an acetogen which produces butyrate from $\mathrm{CO}$ [41]. Butyryl-CoA can be further reduced via butyraldehyde to butanol by NADH-dependent enzymes, analogously to ethanol formation from acetyl-CoA.

If the $\mathrm{Bcd}$ is not electron-bifurcating, the pathway requires $4 \mathrm{NADH}$ and therefore yields $1.2 \mathrm{ATP} /$ butanol. If the Bcd is electron-bifurcating, the additional conservation of energy via the Rnf complex leads to a total ATP yield of 1.8 ATP/butanol. Since 1.4 ATP have to be invested to supply 2 acetyl-CoA, the butanol production from $\mathrm{H}_{2}+\mathrm{CO}_{2}$ via butyraldehyde dehydrogenase has only an energy-positive balance if a bifurcating Bcd is involved (Table 1).
AORs have been shown to reduce a broad range of acids to the corresponding aldehydes, also the reduction of butyrate to butyraldehyde $[42,43]$. The requirement of $\mathrm{Fd}^{2-}$ reduces the energy yield via chemiosmosis, but the formation of butyrate from butyryl-CoA yields 1 ATP via substrate-level phosphorylation. Therefore, the production of butanol via butyrate and an AOR pathway adds $0.4 \mathrm{ATP} /$ butanol to the equation, and therefore, butanol production from $\mathrm{H}_{2}+\mathrm{CO}_{2}$ has a positive energy balance, even without a bifurcating Bcd. Thus, the involvement of a bifurcating Bcd can be a key component for butanol production via butyraldehyde dehydrogenase.

With $\mathrm{CO}$ as electron donor, production of butanol will be strongly energy positive, yielding (dependent on the pathway) 3.4-4.4 ATP per butanol produced. However, butanol production from $\mathrm{CO}$ is also coupled to the production of $\mathrm{CO}_{2}$, according to

$$
12 \mathrm{CO} \rightarrow 1 \text { butanol }+8 \mathrm{CO}_{2}
$$

\section{Production of isoprene}

Isoprene is used for the production of rubber and as precursor for hydrocarbon fuels. Two pathways are known for the formation of isoprene. The mevalonate pathway occurs mainly in eukaryotes and archaea, and the nonmevalonate pathway occurs mainly in bacteria [44]. The mevalonate pathway starts with the condensation of 2 acetyl-CoA, while the non-mevalonate pathway requires pyruvate and glyceraldehyde-3-phosphate as precursors. We will consider here the mevalonate pathway, which 
starts from acetyl-CoA and is not as energy-consuming as the non-mevalonate pathway.

2 acetyl-CoA are condensed to acetoacetyl-CoA. The addition of a third acetyl-CoA yields 3-hydroxy-3-methyl-glutaryl-CoA (HMG-CoA), which is reduced by a $\mathrm{NAD}(\mathrm{P})^{+}$-dependent HMG-CoA reductase to mevalonate. After two consequent ATP-dependent phosphorylations, the formed diphosphomevalonate is decarboxylated at the expense of ATP, giving rise to isopentenyl diphosphate (IPP). After an isomerization, the diphosphate bond is hydrolyzed, yielding isoprene. Thus, in total, the conversion of 3 acetyl-CoA to isoprene requires $2 \mathrm{NAD}(\mathrm{P}) \mathrm{H}$ and $3 \mathrm{ATP}$.

With $\mathrm{H}_{2}$ as electron donor, the supply of $2 \mathrm{NADH}$ for the HMG-CoA reductase reaction yields 0.6 ATP (via hydrogenase, Rnf complex and ATP synthase). Thus, 2.4 ATP have to be invested for the conversion of 3 acetylCoA to isoprene, and the synthesis of 3 acetyl-CoA from $\mathrm{H}_{2}+\mathrm{CO}_{2}$ requires another 2.1 ATP. In sum, 4.5 ATP have to be invested:

$$
12 \mathrm{H}_{2}+5 \mathrm{CO}_{2}+4.5 \mathrm{ATP} \rightarrow 1 \mathrm{CH}_{2} \mathrm{C}\left(\mathrm{CH}_{3}\right) \mathrm{CHCH}_{2} \text {. }
$$

To produce $4.5 \mathrm{~mol}$ of ATP, A. woodii would need to synthesize $15 \mathrm{~mol}$ of acetate for every mol of isoprene produced. Thus, after implementation of the isoprene production pathway by metabolic engineering, acetate still would be the main end product.

With $\mathrm{CO}$ as electron donor, the synthesis of 3 acetylCoA produces 1.5 ATP, and the supply of NADH for the reduction of HMG-CoA delivers another 1.2 ATP (by action of CODH, Rnf complex, and ATP synthase). However, since 3 ATP are required for the phosphorylation and decarboxylation of mevalonate, isoprene production from CO still requires an energy input of 0.3 ATP. Thus, for every isoprene synthesized, $A$. woodii still would have to produce 1 acetate as side product:

$$
12 \mathrm{CO}+0.3 \mathrm{ATP} \rightarrow 1 \mathrm{CH}_{2} \mathrm{C}\left(\mathrm{CH}_{3}\right) \mathrm{CHCH}_{2}+7 \mathrm{CO}_{2}
$$

\section{Other products}

Lactic acid is discussed as biofuel for enzymatic biofuel cells [45]. In addition, it has a large market in food, pharmaceutical, and cosmetics industry, and the production of biodegradable polymers from lactic acid is also in the focus of industrial interests [46]. To form lactic acid from acetyl-CoA, this has to be carboxylated to pyruvate by a pyruvate: ferredoxin oxidoreductase. Further reduction of pyruvate yields lactate. Using NADH as electron donor, the reaction is exergonic by $-25 \mathrm{~kJ} / \mathrm{mol}$. This energy can be used by electron-bifurcating lactate dehydrogenases (LDHs) to reduce ferredoxin, which increases the amount of ATP produced via chemiosmosis [47].
However, even if a bifurcating enzyme is involved, production of lactate from $\mathrm{H}_{2}+\mathrm{CO}_{2}$ still has a negative energy balance by $-0.1 \mathrm{ATP} /$ lactate and, thus, not feasible. If $\mathrm{CO}$ is used as electron donor, the production will be energy positive, even without a bifurcating enzyme.

2,3-butanediol (2,3-BD) is another product that bacteria are capable of producing [25, 48]. 2,3-BD is used as a precursor for the industrial production of solvents and could be used as a fuel additive [49]. Usually, it is produced chemically from oil. If $2,3-\mathrm{BD}$ is produced by acetogens, 2 pyruvate are condensed and decarboxylated, yielding acetolactate. This is further decarboxylated, giving rise to acetoin. The reduction of acetoin with NADH yields 2,3-BD. In sum, 2 acetyl-CoA are reduced with 2 $\mathrm{Fd}^{2-}$ and $2 \mathrm{NADH}$ to 2,3-BD. Whether $\mathrm{H}_{2}$ or $\mathrm{CO}$ is used as external electron donor for the reduction steps has a strong effect on the energy balance: with $\mathrm{H}_{2}, 1.7$ ATP have to be invested for the synthesis of one 2,3-BD, with CO 1.6 ATP are produced for every 2,3-BD synthesized.

Acetone is mainly used as solvent and for the generation of plastics. Microbial production of acetone from starch or glucose via the acetone-butanol-ethanol fermentation process using Clostridium acetobutylicum has been used since World War I [50]. Today, most of the acetone is industrially coproduced with phenol in the cumene process. Microbial production of acetone from $\mathrm{H}_{2}+\mathrm{CO}_{2}$ would require an input of ATP $(-0.4 \mathrm{ATP} /$ acetone), while production from $\mathrm{CO}$ would be coupled to ATP production $(+2.0 \mathrm{ATP} /$ acetone). Acetone can be a precursor for further products. For example, with the patented enzyme system for the acetylation of acetone to 3-hydroxy-isovalerate, followed by the ATP-dependent decarboxylation, isobutene could be produced [51]. Isobutene is a precursor for a lot of different industrial reactions, leading to the production of fuel additives, polymers, and antioxidants. Up to now, it is produced from crude oil.

\section{Production of biofuels using Clostridium autoethanogenum}

Clostridium autoethanogenum was originally isolated for its capability to produce ethanol when growing on $\mathrm{CO}[8]$. Besides ethanol and acetate, the wild-type strain also produces other substances like 2,3-BD and lactate [25]. The genome was published in 2013 and contains several genes encoding for aldehyde: ferredoxin oxidoreductases [52]. C. autoethanogenum contains also an electron-bifurcating hydrogenase, as present in $A$. woodii; however, the purified enzyme was shown to be $\mathrm{NADP}^{+}$-specific. In addition, it forms a complex with the formate dehydrogenase, providing also reducing equivalents for the reduction of $\mathrm{CO}_{2}$ to formate [53]. Measurements with cell-free extract demonstrated the ferredoxin: 
$\mathrm{NAD}^{+}$oxidoreductase activity [54]. Another important difference to the metabolism of $A$. woodii is the presence of an active transhydrogenase, this enzyme couples the exergonic NADPH-dependent reduction of $\mathrm{NAD}^{+}$to the endergonic NADPH-dependent reduction of ferredoxin via flavin-based electron bifurcation. A still unsolved question is the reaction of the MTHFR which could only be measured with artificial dyes. It was suggested that the MTHFR of the MetFV type might reduce ferredoxin via electron bifurcation by building a complex with an electron transfer flavoprotein. Due to this remaining open question, the proposed ATP yield for acetate formation from $\mathrm{H}_{2}+\mathrm{CO}_{2}$ spans from 0.14 ATP/acetate (NADPdependent and non-bifurcating MTHFR) to 1 ATP/acetate (NAD-dependent and bifurcating MTHFR) [54].

Cells of C. autoethanogenum growing on $\mathrm{H}_{2}+\mathrm{CO}_{2}$ produce not only acetate but also ethanol as end product. Activities for the reduction of acetate to acetaldehyde with ferredoxin (AOR), for the reduction of acetyl-CoA to acetaldehyde with NADH and NADPH (CoA acetylating $\mathrm{AldDH}$ ), and the further reduction of acetaldehyde to ethanol $(\mathrm{ADH})$ with $\mathrm{NADH}$ as electron donor were found in cell-free extract of $\mathrm{H}_{2}+\mathrm{CO}_{2}$-grown cells [54]. Dependent on whether the MTHFR reduces ferredoxin and whether acetaldehyde is formed by action of an AOR or a CoA acetylating AldDH, ATP gains ranging from $-0.3 \mathrm{ATP} /$ ethanol to $1.2 \mathrm{ATP} / \mathrm{ethanol}$ can be calculated for the production of ethanol from $\mathrm{H}_{2}+\mathrm{CO}_{2}$ [54].

If a NAD-dependent and electron-bifurcating MTHFR is assumed, as done by Mock and colleagues [54], acetate formation from $\mathrm{H}_{2}+\mathrm{CO}_{2}$ would yield $1 \mathrm{ATP} /$ acetate, and therefore, acetyl-CoA formation from $\mathrm{H}_{2}+\mathrm{CO}_{2}$ would require no ATP input. This would have a tremendous effect on the formation of certain products: the conversion of acetyl-CoA to acetone, for example, yields 1 ATP/acetone produced (Eq. 12):

$$
\begin{aligned}
& 2 \text { acetyl-CoA }+1 \mathrm{ADP}+1 \mathrm{P}_{\mathrm{i}} \\
& \quad \rightarrow 1 \text { acetone }+1 \mathrm{CO}_{2}+1 \mathrm{ATP}
\end{aligned}
$$

Since under the assumed conditions, the synthesis of 2 acetyl-CoA would not require an input of ATP (as is the case in A. woodii, where 0.7 ATP have to be consumed to produce 1 acetyl-CoA from $\mathrm{H}_{2}+\mathrm{CO}_{2}$ ), acetone formation from $\mathrm{H}_{2}+\mathrm{CO}_{2}$ would yield 1 ATP/acetone. However, this is based on the presence of an electronbifurcating MTHFR, but the different scenarios for the mechanism of the MTHFR do not permit exact calculations and predictions of the different pathways.

\section{Simultaneous utilization of $\mathrm{H}_{2}$ and $\mathrm{CO}$}

In times of global warming, processes are required which produce as little $\mathrm{CO}_{2}$ as possible. Syngas consists mainly of $\mathrm{H}_{2}, \mathrm{CO}$, and $\mathrm{CO}_{2}$, and the concentrations of the gases are dependent on the raw material used for the generation of syngas. In syngas-based fermentation processes, $\mathrm{H}_{2}$ can be used as energy source, $\mathrm{CO}_{2}$ as carbon source, and $\mathrm{CO}$ as carbon and energy source. However, the usage of $\mathrm{CO}$ as electron donor goes along with the production of the unwanted $\mathrm{CO}_{2}$, as can be seen in the equations for the production of ethanol and butanol from $\mathrm{CO}$ (Eq. 7, 9). Therefore, fermentation processes where $\mathrm{CO} / \mathrm{CO}_{2}$ are the only carbon sources and all the electrons are derived from $\mathrm{H}_{2}$ would produce no $\mathrm{CO}_{2}$ at all. And indeed, acetogens are known which can grow on syngas by consuming $\mathrm{H}_{2}$ and $\mathrm{CO}$ simultaneously, for example, C. ljungdahlii can convert syngas in a bioreactor with a conversion efficiency for $\mathrm{H}_{2}$ and $\mathrm{CO}$ of almost $100 \%$ [55]. However, the consumption of $\mathrm{H}_{2}$ in the presence of $\mathrm{CO}$ comprises a problem because most hydrogenases known are strongly inhibited by low concentrations of CO. CO-insensitive hydrogenases have been described in carboxydotrophic bacteria and in Knallgas bacteria [56, 57]; however, so far no CO-tolerant hydrogenase has been found in acetogens. And indeed, in the before-mentioned bioreactor with $C$. ljungdahlii, it took 6 days to reach steady-state conditions, and in this time, only $\mathrm{CO}$ was consumed. $\mathrm{H}_{2}$ consumption did not start before the $\mathrm{CO}$ in the inlet gas stream was consumed by $90 \%$. This was also demonstrated in batch cultures of C. ljungdahlii [58]. With pressures of 1.6 and 1.8 atm, $\mathrm{H}_{2}$ consumption did not start before $\mathrm{CO}$ had been almost completely consumed (after $60 \mathrm{~h}$ ). A. woodii does grow on $\mathrm{H}_{2}+\mathrm{CO}_{2}+\mathrm{CO}$ in batch cultures; however, hydrogen oxidation does not start before $\mathrm{CO}$ is completely consumed [9]. The simultaneous consumption of $\mathrm{H}_{2}$ and $\mathrm{CO}$ reported in several publications can be explained with the poor solubility of $\mathrm{CO}$. At certain cell densities, the consumption of $\mathrm{CO}$ can be so high that the concentration of solubilized $\mathrm{CO}$ is low enough to allow simultaneous $\mathrm{H}_{2}$ oxidation. This makes a process possible where $\mathrm{H}_{2}$ is used for the reduction of $\mathrm{CO} / \mathrm{CO}_{2}$; however, optimizing such a process by increasing flow rates or gas pressures might lead to inhibition of $\mathrm{H}_{2}$ consumption. If no $\mathrm{CO}$-insensitive hydrogenase is present in the syngas-converting acetogen, simultaneous oxidation of $\mathrm{CO}$ and $\mathrm{H}_{2}$ in an unlimited system will not be possible.

\section{Conclusions}

From our calculations, it is obvious that with $\mathrm{H}_{2}$ as electron donor, synthesis of most of the products by the pathways discussed here has a negative energy balance. This would lead to the synthesis of unwanted by-products like acetate. Modifications of the pathways can improve the energy yield, which in some cases makes the production energy-positive (ethanol, butanol). With $\mathrm{CO}$ as electron source, synthesis of most products goes along with the 
synthesis of ATP and would, in theory, allow a complete conversion. However, $\mathrm{CO}$ oxidation goes along with production of $\mathrm{CO}_{2}$ which could be circumvented by analogous oxidation of $\mathrm{H}_{2}$. Simultaneous consumption of $\mathrm{H}_{2}$ and $\mathrm{CO}$, however, will be limited by $\mathrm{CO}$-sensitive hydrogenases. By an elaborate selection of the employed organism and implementation of certain enzymes by metabolic engineering, in theory, a $100 \%$ conversion of synthesis gas into many biofuels is feasible.

\section{Abbreviations}

Syngas: synthesis gas, a gas mixture consisting mainly of $\mathrm{H}_{2}, \mathrm{CO}$ and $\mathrm{CO}_{2}$; WLP: Wood-Ljungdahl pathway; THF: tetrahydrofolate; CODH/ACS: CO dehydrogenase/acetyl-CoA synthase; Rnf complex: ferredoxin:NAD+ oxidoreductase; Ech complex: ferredoxin: $\mathrm{H}^{+}$oxidoreductase; MTHFR: methylene-tetrahydrofolate reductase; $\mathrm{HDCR}: \mathrm{H}_{2}$-dependent $\mathrm{CO}_{2}$ reductase; $\mathrm{Fd}^{2-}$ : reduced ferredoxin; AldDH: acetaldehyde dehydrogenase; AOR: aldehyde:ferredoxin oxidoreductase; ADH: alcohol dehydrogenase; FOR: formaldehyde:ferredoxin oxidoreductase; BCD: butyryl-CoA dehydrogenase; HMG: 3-hydroxy-methyl-glutarylCoA; IPP: isopentenyl diphosphate; LDH: lactate dehydrogenase; 2,3-BD: 2,3-butanediol.

\section{Authors' contributions}

JB conceptualized the study, performed the calculations, and drafted the manuscript. VM conceptualized the study, drafted and revised the manuscript. Both authors read and approved the final manuscript.

\section{Acknowledgements}

We are indebted to the Deutsche Forschungsgemeinschaft and the Deutsche Bundesstiftung Umwelt for financial support.

\section{Competing interests}

The authors declare that they have no competing interests.

Received: 6 October 2015 Accepted: 17 November 2015

Published online: 10 December 2015

\section{References}

1. Naik SN, Goud WV, Rout PK, Dalai AK. Production of first and second generation biofuels: a comprehensive review. Renew Sust Energ Rev. 2010;14:578-97.

2. Ajanovic A. Biofuels versus food production: does biofuels production increase food prices? Energy. 2011;36:2070-6.

3. Mussatto SI, Teixeira J. Lignocellulose as raw material in fermentation processes. In: Méndez-Vilas A, editor. Current Research, Technology and Education Topics in Applied Microbiology and Microbial Biotechnology, vol. 2. Badajoz: Formatex Research Centre; 2010. p. 897-907.

4. Dry ME. The Fischer-Tropsch process: 1950-2000. Catal Today. 2002;71:227-41

5. Munasinghe PC, Khanal SK. Biomass-derived syngas fermentation into biofuels: opportunities and challenges. Bioresour Technol. 2010;101:5013-22.

6. Xu D, Tree DR, Lewis RS. The effects of syngas impurities on syngas fermentation to liquid fuels. Biomass Bioenergy. 2011;35:2690-6.

7. Genthner BR, Bryant MP. Growth of Eubacterium limosum with carbon monoxide as the energy source. Appl Environ Microbiol. 1982;43:70-4.

8. Abrini J, Naveau H, Nyns EJ. Clostridium autoethanogenum, sp nov, an anaerobic bacterium that produces ethanol from carbon monoxide. Arch Microbiol. 1994;161:345-51.

9. Bertsch J, Müller V. CO metabolism in the acetogen Acetobacterium woodii. Appl Environ Microbiol. 2015;81:5949-56.

10. Henstra AM, Sipma J, Rinzema A, Stams AJ. Microbiology of synthesis gas fermentation for biofuel production. Curr Opin Biotechnol. 2007;18:200-6.
11. Daniell J, Köpke M, Simpson SD. Commercial biomass syngas fermentation. Energies. 2012;5:5372-417.

12. Schiel-Bengelsdorf $B$, Dürre P. Pathway engineering and synthetic biology using acetogens. FEBS Lett. 2012;586:2191-8.

13. Ragsdale SW. Enzymology of the Wood-Ljungdahl pathway of acetogenesis. Ann NY Acad Sci. 2008;1125:129-36.

14. Müller V. Energy conservation in acetogenic bacteria. Appl Environ Microbiol. 2003;69:6345-53.

15. Drake HL, Gößner AS, Daniel SL. Old acetogens, new light. Ann N Y Acad Sci. 2008;1125:100-28

16. Schuchmann K, Müller V. A bacterial electron bifurcating hydrogenase. J Biol Chem. 2012;287:31165-71.

17. Buckel W, Thauer RK. Energy conservation via electron bifurcating ferredoxin reduction and proton/ $\mathrm{Na}^{+}$translocating ferredoxin oxidation. Biochim Biophys Acta. 2013;1827:94-113.

18. Ferry JG. CO dehydrogenase. Annu Rev Microbiol. 1995;49:305-33.

19. Schuchmann K, Müller V. Autotrophy at the thermodynamic limit of life: a model for energy conservation in acetogenic bacteria. Nat Rev Microbiol. 2014;12:809-21.

20. Biegel E, Müller V. Bacterial Na ${ }^{+}$-translocating ferredoxin: $\mathrm{NAD}^{+}$oxidoreductase. Proc Natl Acad Sci USA. 2010;107:18138-42.

21. Biegel E, Schmidt S, González JM, Müller V. Biochemistry, evolution and physiological function of the Rnf complex, a novel ion-motive electron transport complex in prokaryotes. Cell Mol Life Sci. 2011;68:613-34.

22. Hedderich R, Forzi L. Energy-converting [NiFe] hydrogenases: more than just $\mathrm{H}_{2}$ activation. J Mol Microbiol Biotechnol. 2005;10:92-104.

23. Demler M, Weuster-Botz D. Reaction engineering analysis of hydrogenotrophic production of acetic acid by Acetobacterium woodii. Biotechnol Bioeng. 2010;108:470-4.

24. Kantzow C, Mayer A, Weuster-Botz D. Continuous gas fermentation by Acetobacterium woodii in a submerged membrane reactor with full cell retention. J Biotechnol. 2015;212:11-8.

25. Köpke M, Mihalcea C, Liew F, Tizard JH, Ali MS, Conolly JJ, et al. 2,3-butanediol production by acetogenic bacteria, an alternative route to chemical synthesis, using industrial waste gas. Appl Environ Microbiol. 2011;77:5467-75

26. Schuchmann K, Müller V. Direct and reversible hydrogenation of $\mathrm{CO}_{2}$ to formate by a bacterial carbon dioxide reductase. Science. 2013;342:1382-5.

27. Hess V, Schuchmann K, Müller V. The ferredoxin:NAD ${ }^{+}$oxidoreduc tase (Rnf) from the acetogen Acetobacterium woodii requires $\mathrm{Na}^{+}$ and is reversibly coupled to the membrane potential. J Biol Chem. 2013;288:31496-502.

28. Ragsdale SW, Ljungdahl LG. Purification and properties of NAD-dependent 5,10-methylenetetrahydrofolate dehydrogenase from Acetobacterium woodii. J Biol Chem. 1984;259:3499-503.

29. Bertsch J, Öppinger C, Hess V, Langer JD, Müller V. A heterotrimeric $\mathrm{NADH}$-oxidizing methylenetetrahydrofolate reductase from the acetogenic bacterium Acetobacterium woodii. J Bacteriol. 2015;197:1681-9.

30. Fritz M, Klyszejko AL, Morgner N, Vonck J, Brutschy B, Müller DJ, et al. An intermediate step in the evolution of ATPases: a hybrid $F_{1} F_{0}$ rotor in a bacterial $\mathrm{Na}^{+} \mathrm{F}_{1} \mathrm{~F}_{\mathrm{O}}$ ATP synthase. FEBS J. 2008;275:1999-2007.

31. Thauer RK, Jungermann K, Decker K. Energy conservation in chemotrophic anaerobic bacteria. Bact Rev. 1977;41:100-80.

32. Goodlove PE, Cunningham PR, Parker J, Clark DP. Cloning and sequence analysis of the fermentative alcohol-dehydrogenase-encoding gene of Escherichia coli. Gene. 1989;85:209-14.

33. Extance J, Crennell SJ, Eley K, Cripps R, Hough DW, Danson MJ. Structure of a bifunctional alcohol dehydrogenase involved in bioethanol generation in Geobacillus thermoglucosidasius. Acta Crystallogr D Biol Crystallogr. 2013;69:2104-15.

34. Peng H, Wu G, Shao W. The aldehyde/alcohol dehydrogenase (AdhE) in relation to the ethanol formation in Thermoanaerobacter ethanolicus JW200. Anaerobe. 2008:14:125-7.

35. White $H$, Strobl G, Feicht R, Simon H. Carboxylic acid reductase: a new tungsten enzyme catalyses the reduction of non-activated carboxylic acids to aldehydes. Eur J Biochem. 1989;184:89-96.

36. Basen M, Schut GJ, Nguyen DM, Lipscomb GL, Benn RA, Prybol CJ, Vaccaro BJ, Poole FL 2nd, Kelly RM, Adams MWW. Single gene insertion drives bioalcohol production by a thermophilic archaeon. Proc Natl Acad Sci USA. 2014:111:17618-23. 
37. Chan MK, Mukund S, Kletzin A, Adams MWW, Rees DC. Structure of a hyperthermophilic tungstopterin enzyme, aldehyde ferredoxin oxidoreductase. Science. 1995;267:1463-9.

38. Hu Y, Faham S, Roy R, Adams MWW, Rees DC. Formaldehyde ferredoxin oxidoreductase from Pyrococcus furiosus: the 1.85 A resolution crystal structure and its mechanistic implications. J Mol Biol. 1999;286:899-914.

39. Köpke M, Steffi N, Dürre P. The past, present, and future of biofuelsbiobutanol as promising alternative. In: Bernardes DMADS, editor. Biofuel Production-Recent Developments and Prospects. InTech; 2011

40. Li F, Hinderberger J, Seedorf H, Zhang J, Buckel W, Thauer RK. Coupled ferredoxin and crotonyl coenzyme $\mathrm{A}(\mathrm{Co} \mathrm{A})$ reduction with $\mathrm{NADH}$ catalyzed by the butyryl-CoA dehydrogenase/Etf complex from Clostridium kluyveri. J Bacteriol. 2008;190:843-50.

41. Jeong J, Bertsch J, Hess V, Choi S, Choi IG, Chang IS, et al. Energy conservation model based on genomic and experimental analyses of a carbon monoxide-utilizing, butyrate-forming acetogen, Eubacterium limosum KIST612. Appl Environ Microbiol. 2015;81:4782-90.

42. Ni Y, Hagedoorn PL, Xu JH, Arends IW, Hollmann F. A biocatalytic hydrogenation of carboxylic acids. Chem Commun (Camb). 2012;48:12056-8.

43. Perez JM, Richter H, Loftus SE, Angenent LT. Biocatalytic reduction of short-chain carboxylic acids into their corresponding alcohols with syngas fermentation. Biotechnol Bioeng. 2013;110:1066-77.

44. Kuzuyama T. Mevalonate and nonmevalonate pathways for the biosynthesis of isoprene units. Biosci Biotechnol Biochem. 2002;66:1619-27.

45. Sokic-Lazic D, de Andrade AR, Minteer SD. Utilization of enzyme cascades for complete oxidation of lactate in an enzymatic biofuel cell. Electrochim Acta. 2011;56:10772-5

46. Tokiwa Y, Calabia BP, Ugwu CU, Aiba S. Biodegradability of plastics. Int J Mol Sci. 2009;10:3722-42.

47. Weghoff MC, Bertsch J, Müller V. A novel mode of lactate metabolism in strictly anaerobic bacteria. Environ Microbiol. 2015;17:670-7.

48. Syu MJ. Biological production of 2,3-butanediol. Appl Microbiol Biotechnol. 2001;55:10-8.
49. Celinska E, Grajek W. Biotechnological production of 2,3-butanediol-current state and prospects. Biotechnol Adv. 2009;27:715-25.

50. Dürre P, Bahl H, Gottschalk G. Acetone-butanol fermentation-basis of a modern biotechnological process. Chem-Ing-Tech. 1992;64:491-8.

51. van Leeuwen BN, van der Wulp AM, Duijnstee I, van Maris AJ, Straathof AJ. Fermentative production of isobutene. Appl Microbiol Biotechnol. 2012;93:1377-87.

52. Bruno-Barcena JM, Chinn MS, Grunden AM. Genome sequence of the autotrophic acetogen Clostridium autoethanogenum JA1-1 Strain DSM 10061, a producer of ethanol from carbon monoxide. Genome Announc. 2013;1:e00628.

53. Wang S, Huang H, Kahnt J, Mueller AP, Köpke M, Thauer RK. NADP-specific electron-bifurcating [FeFe]-hydrogenase in a functional complex with formate dehydrogenase in Clostridium autoethanogenum grown on CO.J Bacteriol. 2013;195:4373-86.

54. Mock J, Zheng Y, Mueller AP, Ly S, Tran L, Segovia S, et al. Energy conservation associated with ethanol formation from $\mathrm{H}_{2}$ and $\mathrm{CO}_{2}$ in Clostridium autoethanogenum involving electron bifurcation. J Bacteriol. 2015;197:2965-80.

55. Mohammadi M, Younesi H, Najafpour G, Mohamed AR. Sustainable ethanol fermentation from synthesis gas by Clostridium ljungdahlii in a continuous stirred tank bioreactor. J Chem Technol Biotechnol. 2011;87:837-43.

56. Friedrich B, Fritsch J, Lenz O. Oxygen-tolerant hydrogenases in hydrogenbased technologies. Curr Opin Biotechnol. 2011;22:358-64.

57. Fritsch J, Lenz O, Friedrich B. Structure, function and biosynthesis of $\mathrm{O}_{2}$-tolerant hydrogenases. Nat Rev Microbiol. 2013;11:106-14.

58. Najafpour GD, Younesi $\mathrm{H}$. Ethanol and acetate synthesis from waste gas using batch culture of Clostridium ljungdahlii. Enzyme Microb Technol. 2006;38:223-8.

\section{Submit your next manuscript to BioMed Central and we will help you at every step:}

- We accept pre-submission inquiries

- Our selector tool helps you to find the most relevant journal

- We provide round the clock customer support

- Convenient online submission

- Thorough peer review

- Inclusion in PubMed and all major indexing services

- Maximum visibility for your research

Submit your manuscript at www.biomedcentral.com/submit

C BioMed Central 